\title{
COPEPODS IN SUNDA STRAIT
}

BY

\author{
H. C. DELSMAN
}

After having collected the plankton samples in the Java Sea on which I have reported in Treubia XVII, I939, I thought it desirable to gather similar samples from a more oceanic area of the East Indian seas, in order to be able to make a comparison between the two collections and to try to find out the characteristic differences between the two regions. It seemed to me interesting to choose in the first place Sunda Strait for this purpose, as it connects the shallow Java Sea with the deep Indian Ocean and, therefore, might of fer all degrees of transition from the plankton of the former to that of the latter. The next year, then, in 1933, I made a cruise in Sunda Strait in the months of April-May, the transition months between the (wet) west monsoon and the (dry) east monsoon. The stations visited may be seen from the accompanying chart. The depth increases considerably in the direction Java Sea $\rightarrow$ Indian Ocean but is everywhere sufficient to allow the making of vertical hauls with the plankton net from 50 meters depth to the surface. For the sake of convenience, therefore, all the hauls in Sunda Strait have been made in this way. This was not possible the year before as at several stations in the Java Sea the depth is insufficient. The same net was used as the foregoing year: width of the mouth I $1 / 3 \mathrm{~m}$, length $4 \mathrm{~m}$, Swiss plankton gauze nr. 3 .

In the Sailor's Guide for the East-Indian Archipelago we read:

"This diurnal tidal stream (scil. in the Java Sea) is weakened towards the $\mathrm{NE}$ and strengthened towards the SW in the first place by a current to the SW starting from Bangka-Strait, which runs along the SE-coast of Sumatra and through Sunda Strait at the rate of more than 0.5 Mile per hour.

In the east-monsoon this velocity is greater because then the constant westward stream along the north coast of Java also runs through Sunda Strait."

From this it follows that the whole year round a current runs constantly. from the Java Sea outward through Sunda Strait, as is confirmed by BerLAGE in his paper on the salinity- and current-observations by VAN WEEL 2 ).

There is an outflow of Java-Sea water of lower salinity spreading over the

I) Preliminary Plankton Investigations in the Java Sea, in: Treubia XVII, I939.

2) H. P. Berlage, 1927, Monsoon-currents in the Java Sea and its Entrances. Verhandelingen Kon. Magn. en Meteor. Observatorium, Batavia. 


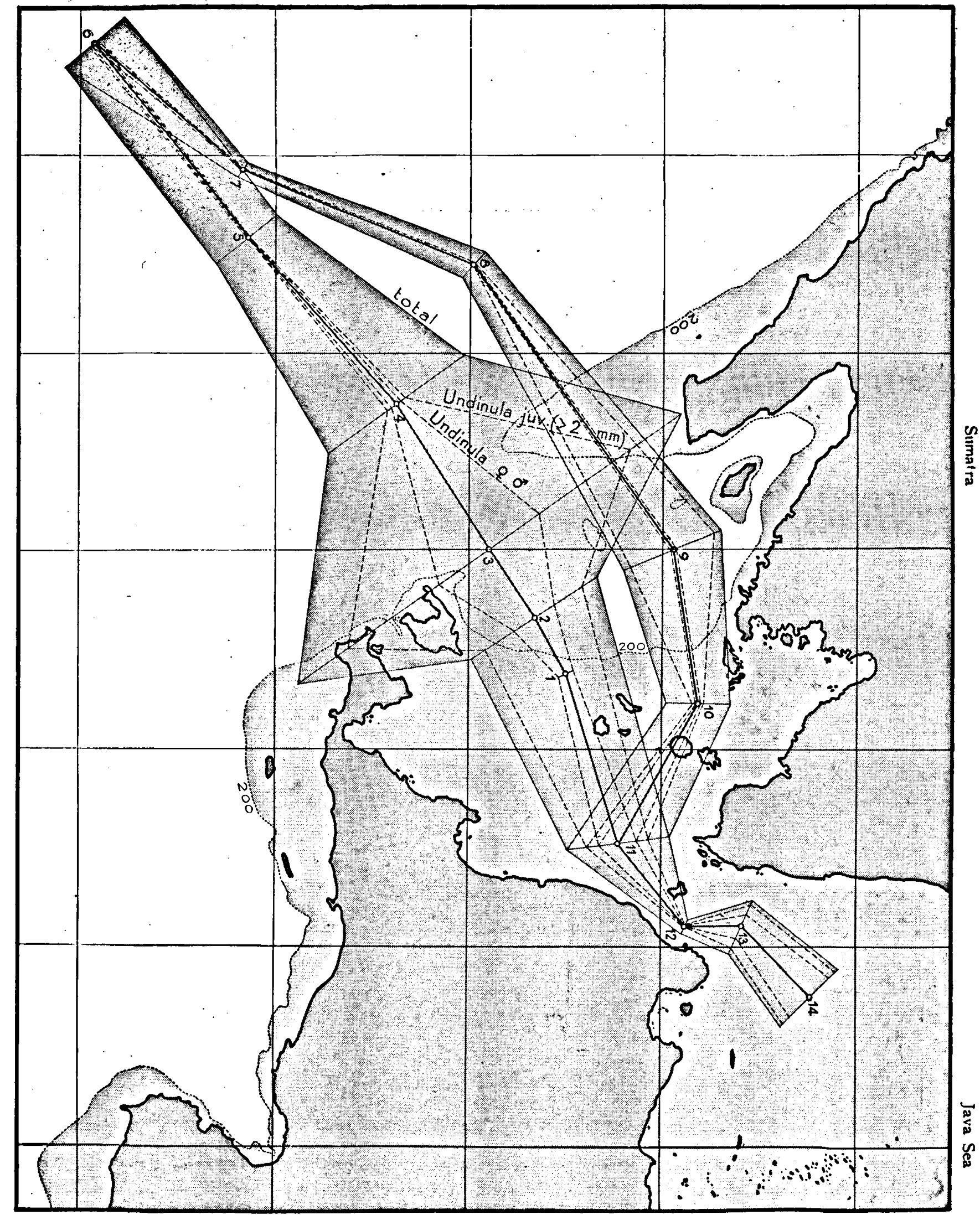

Java

Numbers of copepods bigger than $2 \mathrm{~mm}$ caught during my cruise in Sunda Strait in April-May, 1933. Indicated are also the numbers of Undinula vulgaris $\hat{o}+q$ and $U$. vulgaris copepodid $\mathrm{V}(>2 \mathrm{~mm})$. In this map $1 \mathrm{~mm}$. of the

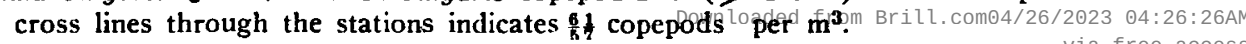


ocean water and gradually mixing with it, so that in Sunda Strait the salinity gradually increases in the direction of the Indian Ocean. The latter stations are found in the middle part of diagram I, the Java Sea stations at both the extremities.

The salinities at the surface are invariably lower. In diagram I we see further that the difference is small at station 12, in the narrowest part of Sunda Strait where tidal currents no doubt cause an intensive mixing of surface and depth water. In the direction of the ocean the surface salinity rises much slower than the salinity at $50 \mathrm{~m}$ where, no doubt, the water mixes earlier with the ocean water. Finally, between stations $5-8$, the surface salinity approaches nearer to that at $50 \mathrm{~m}$, without, however, attaining it.

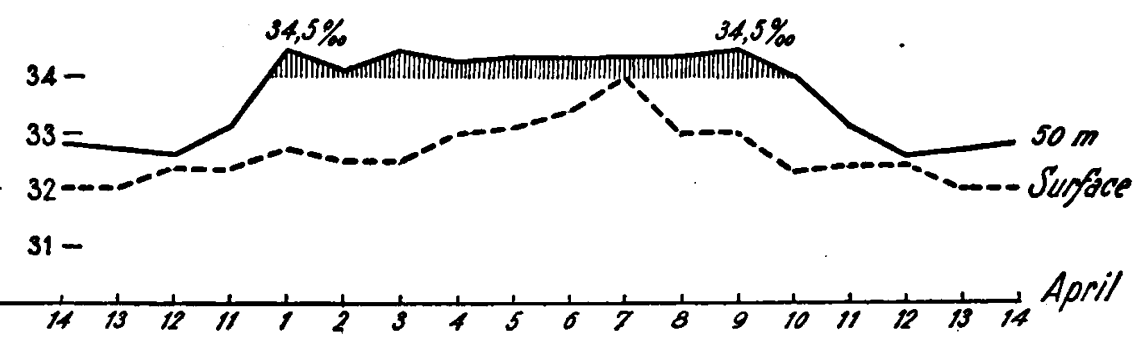

Fig. I. Salinities at the surface and at $50 \mathrm{~m}$.

In the Java Sea the number of Copepod species with a length of $2 \mathrm{~mm}$ or more and which may occur in any considerable quantity doesnot surpass five. A few more species, e.g. Pontella securifer and one or two Labidocera species, may occur singly or in very restricted number.

Passing from the Java Sea into Sunda Strait I saw the number of species increase considerably. Besides the five common species of the Java Sea (Undinula vulgaris, Eucalanus subcrassus, Euchaeta concinna, Candacia bradyi and Labidocera acuta) I found in Sunda Strait, all with a length of $2 \mathrm{~mm}$ or more:

Undinu!a darwini

Eucalanus crassus

, attenuatus

" mucronatus

Rhincalanus cornutus

Neocalanus gracilis

Euchaeta marina

$\begin{array}{cl}\text { Candacia } & \text { aethiopica } \\ " & \text { pachydactyla } \\ " & \text { truncata } \\ " & \text { curta } \\ " & \text { longimana }\end{array}$

Bijdragen tot de Dierkunde, Afl. 28.

\section{Labidocera detruncata}

" minuta

Pontella fera

kröyeri

Pontella princeps

, denticauda

", securifer

Pontellopsis armata

" strenua

" villosa

Pleuromamma abdominalis

$\begin{array}{ll}" & \text { xiphias } \\ , & \text { indica } \\ , & \text { gracilis }\end{array}$




\section{Euchirella venusta pulchra \\ Undeuchaeta bispinosa \\ ”}

Scolecithrix danae

Corycaeus spp.

Copilia sp.

It is not impossible, of course, that some of the above species may be found at some time in the Java Sea too, especially near the western or the eastern entrances, but at any rate it seems fairly evident that they are not common there. We get the impression that the Java Sea resembles he North Sea in that the composition of the plankton is poorer than in the adjacent oceanic waters, several bigger species being absent in this shallow sea with its relatively low salinity.

FaRRAN divided the planktonic copepods from the Barrier Reef Expedition into three groups, viz. the coastal, the open sea and the deep water species Four of the five bigger Java Sea species mentioned above belong to his coastal forms which generally are found inside the reef. Candacia bradyi is not mentioned, and Pontella securifer counted among the open sea forms.

The copepods from Sunda Strait belong for the greater part to his open sea forms, a few (Candacia aethiopica, Labidocera detruncata, Pontella fera) are reckoned by him to be coastal and a few (Pleuromamma abdominalis, xiphias, gracilis) to be deep sea forms.

In FARRAN's paper too the list of open sea species is considerably longe: than that of the coastal forms, and whereas the latter may be fairly complete, the same cannot be said of the former list which no doubt will receive considerable additions from future collecting. The Java Sea plankton, evidently having a coastal character, for this reason seems to be poorer in species than that of the surrounding oceanic waters.

I have counted the copepods of more than $2 \mathrm{~mm}$ length. The results are shown in the chart added to this paper. A look at it shows a strong decrease of the number of copepods in the narrow entrance of Sunda Strait. This can hardly be attributed to the strong tidal currents which prevail here. More likely it seems that the big numbers of echinopluteis which constituted the bulk of the plankton here, are responsible in some way for the deficiency of big copepods. These echinopluteis are present in all the plankton hauls between stations 13 and 5 and also, in a smaller number, at station 9. They have their maxima at stations I2 and I where the curve for the big copepods shows constrictions.

Continuing our way westward through Sunda Strait we see the number of copepods increase towands the western entrance of the Strait, and attain values here higher than I ever found in the Java Sea.

After the maximum attained at station 3 the number of big copepods decreases again and the hauls in the Indian Ocean do not give high values anymore. Much lower are also the values found at the stations more to the north, visited during the way home. If we compare station 7 with 5,8 with 4,9 with 3 and 
2 , and Io with I, then we find a corresponding maximum at 9, and a decrease at 10 and also at 8 and 7 , but all the numbers are considerably lower.

Among the copepods of $2 \mathrm{~mm}$ and more Undinula vulgaris plays an important role, as was the case in the Java Sea. The chart shows the number of adult $\left(\sigma^{\prime \prime}\right.$ and $(Q)$ and of adolescent Undinula, as far as the latter have reached a length of $2 \mathrm{~mm}$, i.e. the copepodid-stage $\mathrm{V}$. The maxima at stations 3 and 9 are mainly due to Undinula vulgaris, adults as well as copepodid-stage V. The number of the latter surpasses that of the former, especially at station 9, so that here a further increase of the number of adults too may be expected. At the Java Sea stations I4, I3 and I2, and also at II, the reverse is the case, from which we might draw the conclusion that they are here decreasing after a culmination period. At the Indian Ocean stations $4,5,6,7$ and 8 , the numbers are too small to draw any conclusion in this respect. Both the maxima, stations 3 and 9, are situated near the border of the continental flat, oceanward of the diatomand $\mathrm{P}_{2} \mathrm{O}_{5}$-maxima (which are not dealt with in this paper). At the oceanic stations, however, Undinula vu!garis is no longer found in any considerable quantity. It is especially at these stations that we find Undinula darwini accompanying $U$. vulgaris without, however, superseding it.

At the oceanic stations other species play a greater role than at the more eastern stations. The number of species of $2 \mathrm{~mm}$ or more does not surpass 5 at the latter stations (nrs. If-I4), it lies between 5 and ro at the middle stations, nrs. I-3 and 8-ro, and above Io at the western, oceanic, stations, nrs. 4-7. The exact figures were:

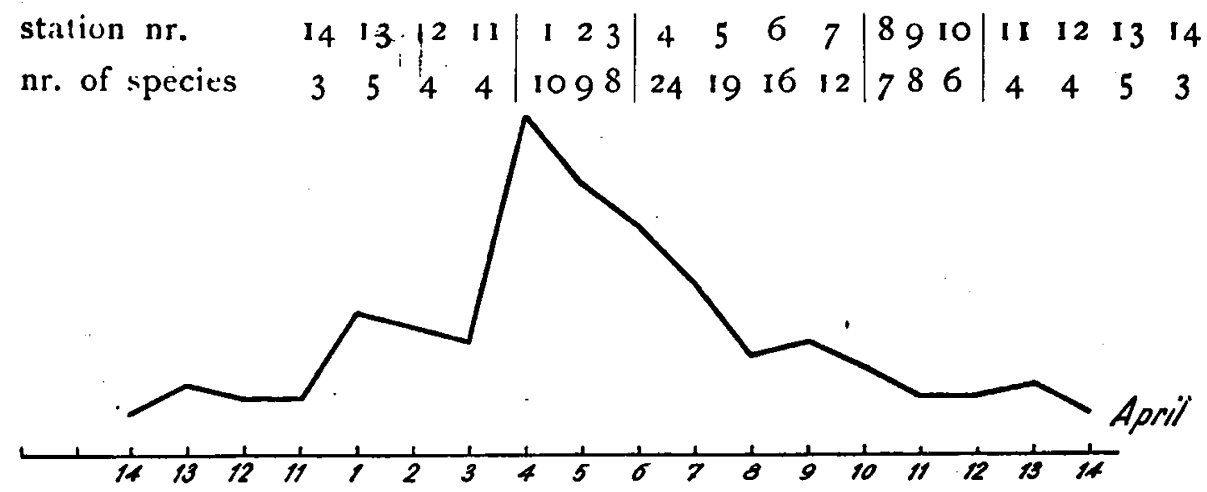

In this list the oceanic stations are again in the middle, the Java Sea stations (incl. station II) on the outer wings (cited 2 times). We see, then, an increase in the number of species going from the Java Sea to the Indian Ocean, in the same way as, going from the southern North Sea through the Channel to the Atlantic Ocean, we see several larger species appear which are absent in the North Sea. The five genera to which the five characteristic big copepods of the Java Sea belong (Undinula, Eucalanus, Euchaeta, Candacia, Labidocera) are represented in Sunda Strait and the Indian Ocean by one or, as a rule, 
more species sometimes accompanying, and sometimes replacing, those of the Java Sea.

Thus, beside Undinula vulgaris we see $U$. darwini appear, beside Eucalanus subcrassus E. crassus, attenuatus and mucronatus, beside Euchaeta concinna E. marina and wolfendeni, beside Candacia bradyi $C$. aethiopica, pachydactyla, curta, truncata and longimana, and beside Labidocera acuta L. detruncata, minuta and kröyeri. I have found some of these species, as e.g. Labidocera kröyeri, also in the Java Sea, though rarely. The general impression, however, is that the fauna of the Java Sea, at least as regards the bigger species, is considerably poorer than that of the ocean.

A similar cruise made in October of the same year gave, as a consequence of bad weather, less complete results.

If, however, we compare the diagram for October with the April diagram then we are reminded of what we found in the Java Sea : a certain likeness of the two curves but in April much higher numbers than in October.

In both the transition months between the monsoons maxima are found in the middle part of Sunda Strait, though not exactly at the same stations, and a tapering of the curve towards the Indian Ocean as well as towards the narrowest part of the Strait, viz. the northeirn entrance. At the Java Sea stations higher numbers are found again.

In how far the curves for 1933 may be considered as characteristic for the transition periods in other years may only be determined by continued observations. With this reserve we venture the conclusion that the middle of Sunda Strait seems to be a fairly favourable feeding ground especially for pelagic fishes.

For the sake of curiosity it may be mentioned here that near the station 3 we observed a small shoal of big whales which were approached by us very closely. Whales are rare in Indian waters, probably they do not find there sufficient planktonic food. Is it merely by chance that we met them near the station where the highest values for the bigger copepods were found? 